\title{
京都市におけるトウカエデ街路樹の根上がりと ボーリング調査データからみた土壌条件との関係について
}

The Relationship between the Incidence of the Pavement/Curb Failure by Street Tree Roots and Soil Conditions of Boring Investigation Data in Urban Area of Kyoto City

\author{
瀬古 祥子* 福井 亘* \\ Sachiko SEKO Wataru FUKUI
}

\begin{abstract}
There is a problem that the roots of street trees lift up and break many pavements and curbs. The purpose of this research is to know the relationship between surrounding conditions and the incidence of the pavement/curb failure by street tree roots in urban area of Kyoto city. We focused on the soil condition as the factors of surrounding conditions and chose trident maple (Acer buergerianum Miq.) as the subject. Site of this research is one of the main streets running north-south in Kyoto city. In this case, we used boring investigation data to know general soil condition around street trees. Through this survey, we could know some possible factors of the trouble. For example, the incidence rate in humus soil is highest, and the extent of root growths are influenced by the firmness of soil and groundwater level around planted space. The disadvantage of this research is each result has fuzzy aspects because we didn't carry out the soil investigation directly. However, through this research, we found the boring data has some possibilities to complement a lot of soil investigations to know general soil condition around street trees.
\end{abstract}

Keywords : Street trees, the pavement/curb failure by tree roots, soil condition, boring investigation data, GIS, Kyoto city キーワード：街路樹，根による舗装や縁石の破損，土壌条件，ボーリングデータ，GIS，京都市

\section{1. 背景と目的}

街路樹の植栽にあたっては，植栽栘以外の歩道下部や車道下部

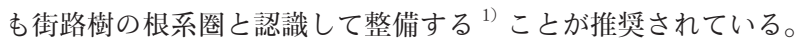
しかし，踏圧や根系生長による土㙵の圧密化・堅密化や経年的な 理化学性の変化, 地下埋設物との競合などにより, 歩道下部は樹

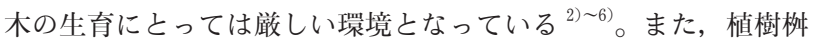
の狭小さも指摘されており, 限られた幅と深さで土㙵改良が行わ れた桝内で生育している街路樹の根系が樹体維持や養水分摂取の ために栘の外へと伸長し, 舗装などに影響をおよぼすという課題

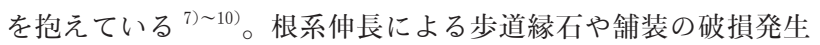
は根上がりと呼ばれており ${ }^{7)}$, これまで, 地中を掘削して歩車道下 部の根系域と生育状態を調査した研究や, 歩道面の破損状況を調 查した研究, 根上がり対策のための工法の検討などがなされてき

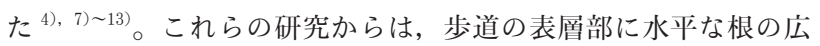
がりが多いことや胸高周囲長（以下，周囲長）が大きくなるほど 根上がりの発生が多くなること, 縁石から舗装の持ち上がりへと 順に発生し, 舗装の種類や樹種によって根上がりの発生に違いが あること, 根上がりの生じやすい樹種などが報告されている。また, 通行に支障があり緊急性の高い区間や樹木の更新, 新規植栽基盤 整備にあたって効果的な工法が採用されている事例もみられる。

長期的には根系誘導耐圧基盤などの効果的な工法を広く検討し ていく対策が望まれる。一方, 併せて既存の植栽環境における基 盤外の環境条件を検討し, 今後の整備にあたっての留意点を検討 していく必要があると考えられる。植栽環境の調査としては, 植 栽基盤直下を掘削することが最も望ましいが, 実際に掘削を行っ た調査では歩道通行の障害となることや樹木自体への負担がかか るため，量的には行うことができない点も指摘されている。

そこで本研究では, 建築行為や災害対策のために行われ, 地域 の地下構造を知ることのできるボーリング調査データの活用を試 みた。街路周辺の全般的な土壤条件と街路樹の根上がり発生状況 との関連性を検討するとともに，ボーリング調査データによるデー
夕代替の限界とその可能性について検討を行った。

\section{2. 研究方法}

\section{(1) 調査対象}

調査対象地は紅葉景観創出と落ち葉負担軽減のための剪定方法 の導入など, 先駆的な街路樹行政がなされている京都市とし た ${ }^{15)}$ 。調査の対象街路は, 図-1に示す, 京都市市街地の西部 に南北方向に伸びる主要通りである西大路通とした。

本研究では京都市の約 49,000 本ある街路樹の中で 2 番目に植 栽本数が多く，対象通りに扔ける樹木更新にあたって新植が行わ れているトウカエデ (Acer buergerianum Miq.) を分析対象と した。最新樹木根系図説 ${ }^{16)}$ を参考に, トウカエデの根系の特徵 をまとめ，表一 1 に示した。

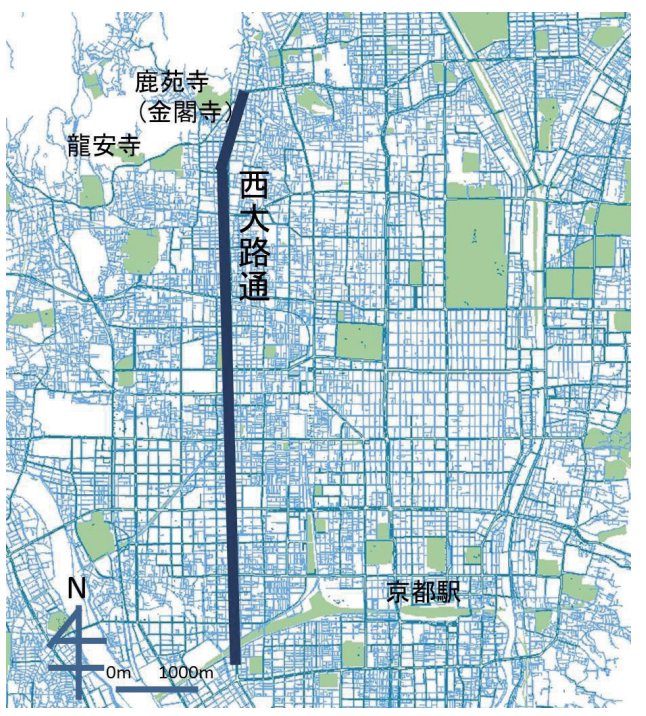

図-1 調査対象地（太線表示：西大路通） 
表 -1 調査対象樹種 : トゥカエデの根系特性 ${ }^{16)}$

\begin{tabular}{|c|c|c|c|c|}
\hline \multicolumn{5}{|c|}{ トウカエデ } \\
\hline 根系形態 & 垂直分布 & 水平分布 & 耐堅密性 & 土性 \\
\hline $\begin{array}{c}\text { 大径の斜出根 } \\
\text { 垂下根型 }\end{array}$ & 浅根型 & 中間型 & 大 & 砂質〜埴質 \\
\hline
\end{tabular}

※而摼密性：山中式硬度計で指標硬度 $24 \mathrm{~mm}$ 以上に耐えられるもの

※土性 : 根系の働きと生長に適した土壌 ${ }^{16)}$
表 -2 砂質土・粘性土の相対密度・相対稠度

\begin{tabular}{|c|c|c|c|c|c|}
\hline \multicolumn{6}{|c|}{ 土袞硬度 : 相対密度 - 相対椆度 } \\
\hline \multirow{6}{*}{$\begin{array}{l}\text { 砂 } \\
\text { 質 } \\
\text { 土 }\end{array}$} & & $\mathrm{N}$ 值 & \multirow{6}{*}{$\begin{array}{l}\text { 粘 } \\
\text { 性 } \\
\text { 土 }\end{array}$} & & $\mathrm{N}$ 值 \\
\hline & 非常にゆるい & $\sim 5$ & & 極軟 & $\sim 2$ \\
\hline & ゆるい & $5 \sim 10$ & & 軟 & $2 \sim 4$ \\
\hline & \multirow[t]{2}{*}{ 中 } & $10 \sim 20$ & & 中 & $4 \sim 8$ \\
\hline & & $20 \sim 30$ & & 硬 & $8 \sim 15$ \\
\hline & 密 & $30 \sim$ & & 極硬 & $15 \sim$ \\
\hline
\end{tabular}

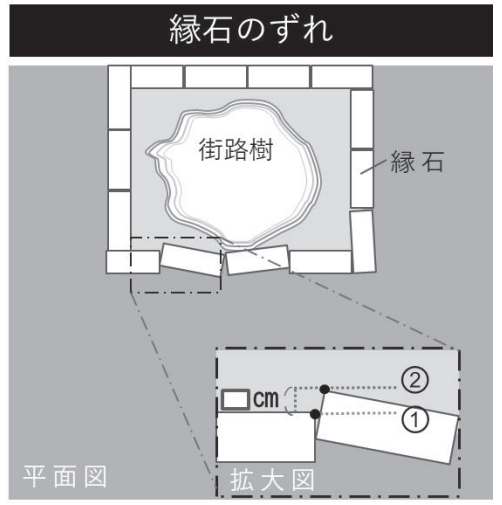

歩道舗装のひび割れ

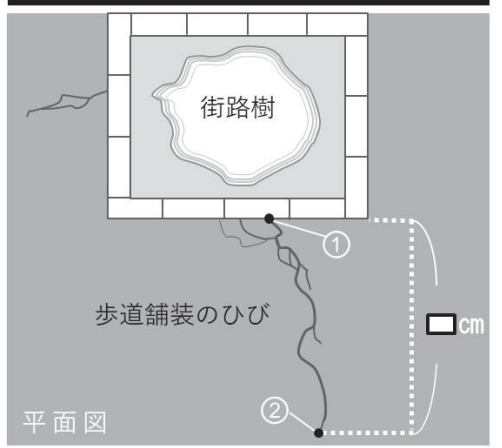

図－２＼cjkstart根上がりの種類ごとの実測箇所図

\section{（2）調査方法}

1 ）現地調査による街路樹の根上がり発生状況の把握

調查対象通りにおけるトウカエデ街路樹の根上がり発生状況を 確認するため, 植樹桝の縁石や歩道舗装に破損が生じている街路 樹の本数および破損の程度 (長さ), 樹木の胸高周囲長, 植樹栘 の奥行などを実測した。根上がりの種類は, 植樹栘の縁石がずれ ているもの，縁石が持ち上がっているもの，歩道の舗装がひび割 れているもの, 舗装が持ち上がっているもの, 根元の上根部分が 植樹栘からあふれ出しているもの（縁石の巻き込み）の 5 種が確 認された。本研究では縁石のずれ・持ち上げ，歩道のひび割れ・

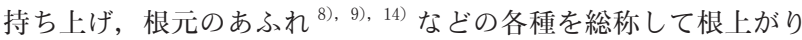
と定義している。写真－1には，歩道のひび割れや根元のあふれ 出しが生じている街路樹の事例を示した。これら破損部分の実測 箇所を図化し根上がりの形態ごとに図－2 に示した。縁石のずれ の実測については図－2 に示したように，縁石の内辺（図中(1) からずれが生じた縁石の端部（図中(2)）までの長さを計測した。 縁石の持ち上げについては, 歩道面 (図中(1) から持ち上がった 高さ（図中(2)まで）を計測した。歩道舗装のひび割れと持ち上げ については, 縁石の外辺 (図中(1) からひび割れ之隆起箇所の端 部（図中(2)）までの長さを計測した。根元のあふれ出しについて は, 縁石の内辺 (図中(1) ) から上根端部 (図中(2) までの長さを

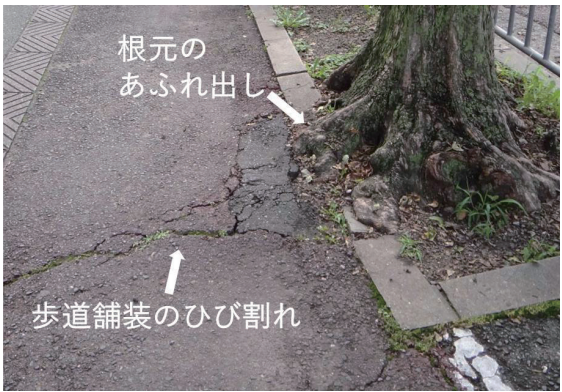

写真－1トウカエデ街路樹の根上がり事例

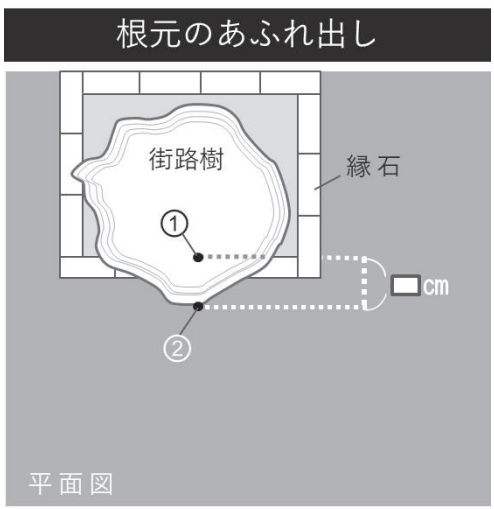

計測した。いずれも基準とする隣接の縁石もしくは歩道面から端 部にかけて直角方向に計測し，隣接する縁石が歪んでいるなどし て基準点とすることが困難な場合は同桝内で歪みが生じていない 縁石を基準点とした。なお，地表面に何らかの変化が現れるとい うことは, 地下ではすでに圧密な環境となっている可能性がある ${ }^{4), 9)}$ ため, $5 \mathrm{~mm}$ 程度の極めて微細なものであっても, 上根の伸長方 向にずれ等がみられた場合は計測の対象とした。同じ街路樹から 複数のひび割れやずれ，広範囲への持ち上げが生じていた場合は， 最大值のみを記録した。調査は 2013 年から 2014 年の夏季にかけ て行った。現地調查の際, 低木の植え込みが繁茂している箇所や 看板類の設置により実測が困難であった箇所は調査対象から除外 している。また，以前同じ場所に植樹されていた街路樹の根上が りによる破損箇所が補修されていない場合などもあるため，平成 19 年京都市街路樹台帳 ${ }^{17)}$ に記録された街路樹の胸高周囲長之樹 種を確認し，「平成 19 年の周囲長 $<$ 平成 25 年の周囲長」以外の 街路樹，および樹種の異なるものは調査対象から除外した。すな わち, 平成 20 年以降に新しく植栽された街路樹が除外されている。 2 ) 資料調查による土壤条件の把握

土㙴条件については, 関西圈地盤情報データベース（関西圈地 盤 DB） ${ }^{18)}$ に記載されたボーリング調査箇所とボーリング柱状図 を基に，土質および土㙵硬度，地下水位を確認した。 


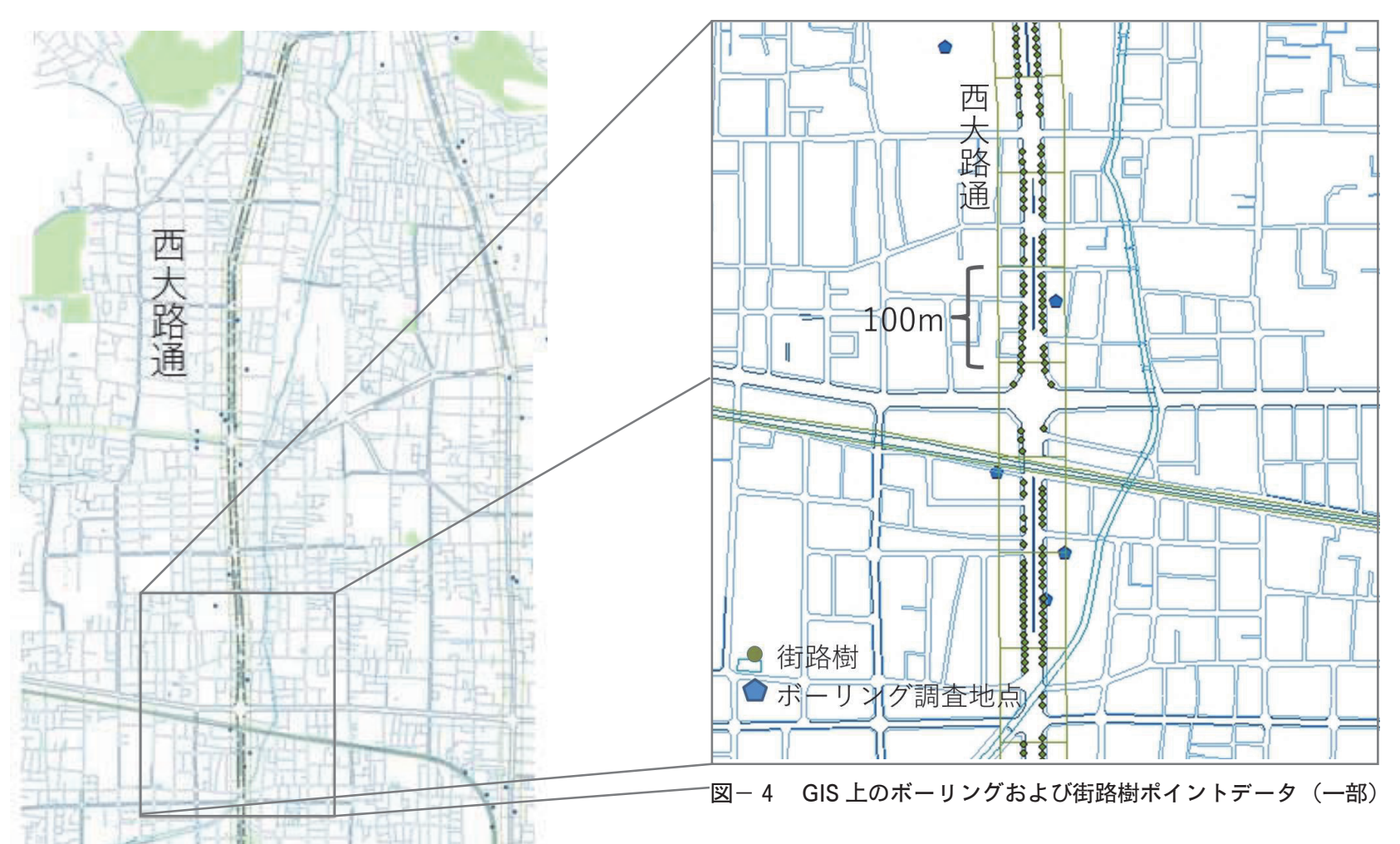

土質は, 関西圈地盤 DB の凡例に基づき， 10 種類に分類した。 土培硬度は表 -2 に示した砂質土と粘性土の相対密度と相対稠度 として N 值（地盤の標準貫入試験値）を相対化した值を用いた。 具体的には，表一 2 に示した砂質土の $\mathrm{N}$ 值と粘性土の $\mathrm{N}$ 值に対 応して, 砂質土の值 4 までおよび粘性土の值 1 は「1」, 砂質土の 值 5, 6 押よび粘性土の值 2 は「2」, 砂質土の值 7,8 および粘性 土の值 3 は「3」, 砂質土の值 9,10 および粘性土の值 4 は「4」 としてデータ入力を行った。地下水位については, 柱状図に記載 されている数值を解析に用いた。また，柱状図から読み取る深度 は，良好とされる必要有効土層 ${ }^{1)}$ を参考に地表から土境深 $2 \mathrm{~m}$ までとした。具体的には， $0.5 \mathrm{~m} ， 1.0 \mathrm{~m}, 1.5 \mathrm{~m}, 2.0 \mathrm{~m}$ の土質と硬 度を確認した。

3) GIS データベース化

本研究では, 地理情報システム（GIS）により調查結果のデー 夕を作成した。街路の基盤となるデー夕は, 国土地理院発行の「数 值地図 $2500 」^{19)}$ であり，GIS のソフトウェアは，ESRI 社製の Arc GIS（Arc View 10.0）である。

実測調查ののち, 調查対象範囲の全ての街路樹の位置を GIS にてポイントデータとして入力し, ボーリングの位置についても 同様にポイントデータとして入力した。また，根上がり発生状況 と周辺土壌条件との解析に際して, ボーリング調查の行われた地 点は等間隔ではないため, 最も近い距離にある $100 \mathrm{~m}$ 間隔でグルー プ化した街路樹のみを抽出し, 関連性を確認した。ボーリング調 査地点間の距離が広く空いている場合には, 中間の地盤の状態を 把握することができない。ボーリング調查地点と対応させる, 最 も近い街路樹の範囲の選択にあたっては, 道路事業の地盤調查に おけるボーリング地点の間隔の $50 \mathrm{~m} \sim 200 \mathrm{~m}$ の目安を参考として, 本調査では $100 \mathrm{~m}$ 範囲を用いて検討を試みた。ボーリング調査が 通りの東側で行われていた場合には東側歩道の街路樹デー夕を, 西側の場合は西側歩道の街路樹デー夕を用いた。

\section{(3) 分析方法}

統計学的分析にあたっては，いずれもエクセル統計 2012 (SS RI）を使用し，分散分析および多重比較 (Tukey 法)，相関行列 の作成, 無相関の検定を行った。 


\section{表－3＼cjkstart西大路通における調査対象樹木植栽箇所の街路環境構成}

\begin{tabular}{|c|c|c|c|c|c|c|c|c|c|c|c|c|c|}
\hline \multirow[b]{2}{*}{ 対象通 } & \multirow[b]{2}{*}{ 東西 } & \multicolumn{3}{|c|}{ 植樹栘の構成 : \% (本数) } & 植樹桝形状 & \multicolumn{4}{|c|}{ 舗装の構成 : \% (本数) } & \multicolumn{3}{|c|}{ 歩車道： m } & \multirow{2}{*}{\begin{tabular}{|c|} 
沿道土地利用 \\
住居地域 \\
近隣商業地域 \\
商業地域
\end{tabular}} \\
\hline & & 単独桝 & 連続桝 & 花壇型 & $\begin{array}{c}\text { 奥行 } \\
\text { 平均值: } \mathrm{cm} \\
\text { 中央值: } \mathrm{cm}\end{array}$ & $\mid \begin{array}{l}\text { インター } \\
\text { ロッキングブロック }\end{array}$ & $\begin{array}{l}\text { アス } \\
\text { ファルト }\end{array}$ & $\begin{array}{l}\text { インター } \\
\text { ロッキング+ } \\
\text { アスファルト }\end{array}$ & タイル & $\begin{array}{c}\text { 歩道幅員 } \\
\text { 平均値 } \\
\text { 土標準偏差 }\end{array}$ & $\begin{array}{c}\text { 車道幅員 } \\
\text { 平均値 } \\
\text { 土標準偏差 }\end{array}$ & 道路の種類 & \\
\hline \multirow{2}{*}{ 西大路 } & 東側 & $29.4(35)$ & $70.6(84)$ & 0.0 & \multirow{2}{*}{$\begin{array}{l}93.4 \\
85.0\end{array}$} & $26.0(31)$ & $72.3(86)$ & $0.0(0)$ & $1.7(2)$ & $4.1 \pm 0.4$ & \multirow[b]{2}{*}{$19.7 \pm 1.5$} & \multirow[b]{2}{*}{ 主要市道 } & \multirow{2}{*}{$\begin{array}{c}\text { 住居 } \\
\text { 近隣商業 } \cdot \text { 商業 }\end{array}$} \\
\hline & 西側 & $40.2(45)$ & $59.8(67)$ & 0.0 & & $46.4(52)$ & $53.6(60)$ & $0.0(0)$ & $0.0(0)$ & $4.4 \pm 0.5$ & & & \\
\hline
\end{tabular}

※調査対象樹木本数：東側 119 本, 西側 112 本, 合計 231 本

表－４トウカエデ街路樹の根上がり発生状況

\begin{tabular}{|c|c|c|c|c|c|c|c|c|}
\hline \multirow[b]{2}{*}{ 対象通 } & \multirow[b]{2}{*}{ 東西 } & \multicolumn{6}{|c|}{ 根上がりの種類別の割合と本数 : \% (本数) } & \multirow{2}{*}{$\begin{array}{l}\text { 平均周囲長 : } \mathrm{cm} \\
\text { 平均値士標準偏差 }\end{array}$} \\
\hline & & $\begin{array}{c}\text { 根上がり計 } \\
\text { (各種類間の重複を除く) } \\
\end{array}$ & 根元あふれ & 縁石持ち上げ & 縁石ずれ & 歩道持ち上げ & 歩道ひび & \\
\hline \multirow{4}{*}{ 西大路 } & 東側 & $41.2(49)$ & $21.0(25)$ & $16.0(19)$ & $20.2(24)$ & $12.6(15)$ & $5.0(6)$ & $80.2 \pm 31.5$ \\
\hline & 西側 & $34.8(39)$ & $12.5(14)$ & $15.2(17)$ & $14.3(16)$ & $22.3(25)$ & $12.5(14)$ & $78.5 \pm 32.6$ \\
\hline & \multirow{2}{*}{$\begin{array}{c}\text { 根上がりの } \\
\text { 程度 }\end{array}$} & 長さ·高さの最大値 : cm & 25.0 & 30.0 & 6.0 & 75.0 & 120.0 & \\
\hline & & $\begin{array}{c}\text { 長さ·高さ: } \mathrm{cm} \\
\text { 平均値士標準偏差 }\end{array}$ & $7.7 \pm 5.8$ & $3.1 \pm 4.8$ & $2.3 \pm 1.5$ & $34.7 \pm 16.4$ & $82.6 \pm 46.5$ & \\
\hline
\end{tabular}

※調査対象樹木本数：東側 119 本，西側 112 本，合計 231 本

表－ 5 西大路通におけるボーリングデータからみた土壤条件（土質）と根上がり発生割合

\begin{tabular}{|c|c|c|c|c|c|c|c|}
\hline \multirow[b]{2}{*}{ 深度 } & \multirow{2}{*}{$\begin{array}{l}\text { 有効調査 } \\
\text { 街路樹数 }\end{array}$} & \multicolumn{4}{|c|}{ 土質割合 : \% (本数) } & \multirow{2}{*}{$\begin{array}{c}\text { 土壌硬度相対值 } \\
\text { 平均值 }\end{array}$} & \multirow{2}{*}{$\begin{array}{c}\text { 地下水位 } \\
\text { 平均值 : } m\end{array}$} \\
\hline & & 砂質土 - 磁 & 粘土 - シルト & 有機質土 & その他 & & \\
\hline $0.5 \mathrm{~m}$ & 230 & $35.2(81)$ & $32.2(74)$ & $9.1(21)$ & $23.5(54)$ & 4.0 & \\
\hline $1.0 \mathrm{~m}$ & 231 & $42.9(99)$ & $37.2(86)$ & $9.5(22)$ & $10.4(24)$ & 5.1 & \\
\hline $1.5 \mathrm{~m}$ & 226 & $51.3(116)$ & $39.8(90)$ & $4.0(9)$ & 4.9 (11) & 10.3 & 2.5 \\
\hline $2.0 \mathrm{~m}$ & 227 & $50.7(115)$ & 40.5 (92) & $4.4(10)$ & $4.4(10)$ & 14.7 & \\
\hline
\end{tabular}

表－６＼cjkstart西大路通のボーリングデータからみた土質別の植樹栘奥行比較

\begin{tabular}{|c|r|c|c|c|}
\hline & 植樹桝奥行平均值士標準偏差 : cm & F 值 & P 值 & 多重比較判定 \\
\hline 砂質土 & $98.9 \pm 4.9$ & \multirow{2}{*}{0.437} & 0.646 & \\
\cline { 1 - 2 } 粘性土 & $96.5 \pm 3.2$ & & & \\
\cline { 1 - 2 } 有機質土 & $105.9 \pm 13.3$ & & & \\
\cline { 1 - 2 }
\end{tabular}

表－７西大路通のボーリングデータからみた土質別の街路樹の胸高周囲長比較

\begin{tabular}{|c|c|c|c|c|c|}
\hline & 胸高周囲長平均値土標準偏差 : $\mathrm{cm}$ & $\mathrm{F}$ 值 & $\mathrm{P}$ 值 & \multicolumn{2}{|c|}{ 多重比較判定 } \\
\hline 砂質土 & $78.9 \pm 3.3$ & \multirow[t]{3}{*}{12.616} & \multirow[t]{3}{*}{0.004} & \multirow{3}{*}{$7 * *$} & \multirow{3}{*}{$7 * *$} \\
\hline 粘性土 & $73.0 \pm 3.4$ & & & & \\
\hline 有機質土 & $108.5 \pm 4.3$ & & & & \\
\hline
\end{tabular}

表－8 西大路通のボーリングデータからみた土質別の街路樹の土壇硬度比較

\begin{tabular}{|c|c|c|c|c|}
\hline & 土壌硬度平均値土標準偏差 : $\mathrm{cm}$ & $\mathrm{F}$ 値 & $\mathrm{P}$ 値 & 多重比較判定 \\
\hline 砂質土 & $1.9 \pm 0.1$ & \multirow[t]{3}{*}{10.814} & \multirow[t]{3}{*}{0.000} & \multirow[t]{3}{*}{$* *$} \\
\hline 粘性土 & $6.4 \pm 1.0$ & & & \\
\hline 有機質土 & $2.4 \pm 0.3$ & & & \\
\hline
\end{tabular}

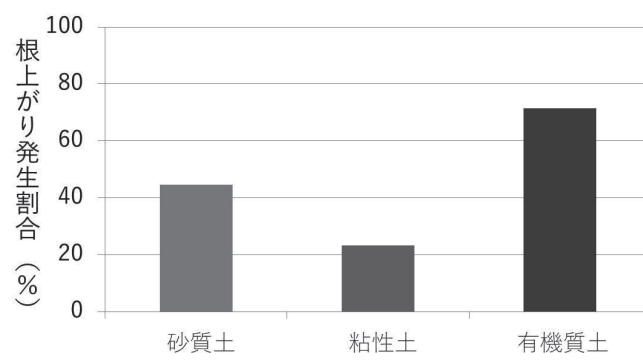

土壤の種類

図－５土質別根上がり発生割合（深度 $0.5 m$ )

表－9 西大路通におけるボーリングデータからみた土壌条件（土壤硬度）と街路樹の根上がりの程度との関連性

\begin{tabular}{|c|c|c|c|c|c|c|c|c|c|c|c|c|c|}
\hline 深度 $0.5 \mathrm{~m}$ & $\begin{array}{l}\text { 根元 } \\
\text { あふれ }\end{array}$ & $\begin{array}{c}\text { 縁石 } \\
\text { 持上げ }\end{array}$ & $\begin{array}{l}\text { 縁石 } \\
\text { ずれ }\end{array}$ & $\begin{array}{c}\text { 歩道 } \\
\text { 持上げ }\end{array}$ & $\begin{array}{l}\text { 歩道 } \\
\text { ひび }\end{array}$ & $\mathrm{N}$ 值 & 深度 $1.0 \mathrm{~m}$ & $\begin{array}{l}\text { 根元 } \\
\text { あふれ }\end{array}$ & $\begin{array}{c}\text { 縁石 } \\
\text { 持上げ }\end{array}$ & $\begin{array}{l}\text { 縁石 } \\
\text { ずれ }\end{array}$ & $\begin{array}{c}\text { 歩道 } \\
\text { 持上げ }\end{array}$ & $\begin{array}{l}\text { 歩道 } \\
\text { ひび }\end{array}$ & $\mathrm{N}$ 值 \\
\hline $\mathrm{N}$ 值 & 0.305 & -0.233 & -0.220 & 0.064 & .514 & & $\mathrm{~N}$ 值 & 0.167 & -0.177 & -0.226 & 0.042 & 0.315 & \\
\hline 胸高周囲長 & 029 & 165 & 0.392 & 07 & 0.273 & 0.108 & 胸高周囲長 & 1 & 3 & 0.278 & 122 & 0.410 & 0.043 \\
\hline 植樹桝外奥行 & 0.221 & 0.089 & -0.277 & -0.182 & -0.340 & & 植樹桝奥行 & 0.061 & 0.121 & -0.298 & 0.110 & -0.377 & 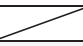 \\
\hline 深度 $1.5 \mathrm{~m}$ & $\begin{array}{l}\text { 根元 } \\
\text { あふれ }\end{array}$ & $\begin{array}{c}\text { 縁石 } \\
\text { 持上げ }\end{array}$ & $\begin{array}{l}\text { 縁石 } \\
\text { ずれ }\end{array}$ & $\begin{array}{c}\text { 歩道 } \\
\text { 持上げ }\end{array}$ & $\begin{array}{l}\text { 歩道 } \\
\text { ひび }\end{array}$ & $\mathrm{N}$ 值 & 深度 $2.0 \mathrm{~m}$ & $\begin{array}{l}\text { 根元 } \\
\text { あふれ }\end{array}$ & $\begin{array}{c}\text { 縁石 } \\
\text { 持上げ }\end{array}$ & $\begin{array}{c}\text { 縁石ず } \\
\text { れ }\end{array}$ & $\begin{array}{c}\text { 歩道 } \\
\text { 持上げ }\end{array}$ & $\begin{array}{l}\text { 歩道 } \\
\text { ひび }\end{array}$ & $\mathrm{N}$ 値 \\
\hline $\mathrm{N}$ 値 & $0.532 * *$ & 0.075 & 0.285 & -0.165 & 0.044 & & $\mathrm{~N}$ 値 & -0.07 & 0.209 & -0.295 & $-0.385^{*}$ & -0.384 & $\gamma$ \\
\hline 胸高周囲長 & 0.350 & -0.029 & 0.151 & 0.016 & 0.222 & $0.316^{*}$ & 胸高周囲長 & 0.344 & -0.029 & 0.129 & 0.013 & 0.221 & 0.133 \\
\hline 植樹桝懊行 & -0.210 & 0.140 & -0.164 & -0.082 & -0.404 & & 植樹桝奥行 & -0.218 & 0.139 & -0.205 & -0.083 & -0.430 & \\
\hline
\end{tabular}

( 無相関の検定, ${ }^{*} p<0.05,{ }^{* *} \quad p<0.01$ )

表一10 西大路通におけるボーリングデータからみた土壤条件（地下水位）之街路樹の根上がりの程度との関連性

\begin{tabular}{|c|c|c|c|c|c|}
\hline \multirow{2}{*}{ 地下水位 } & 根元あふれ & 縁石持ち上げ & 縁石ずれ & 歩道持ち上げ & 歩道ひび \\
\cline { 2 - 6 } & $0.445^{* *}$ & -0.149 & 0.144 & 0.047 & -0.480 \\
\hline
\end{tabular}

( 無相関の検定, ${ }^{*} p<0.05,{ }^{* *} \quad p<0.01$ ) 


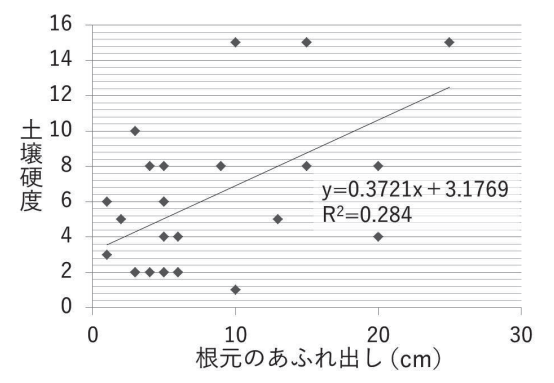

図－6＼cjkstart根元のあふれ出しと土壤硬度（深度 $1.5 \mathrm{~m}$ ）

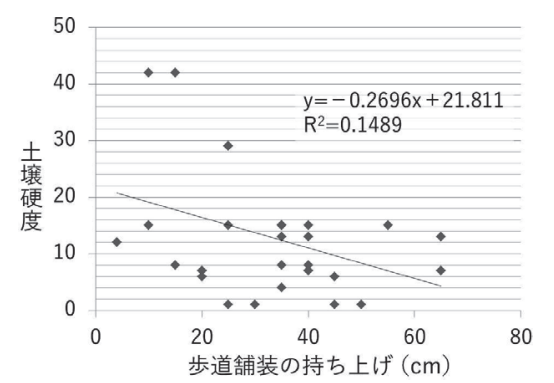

図-7 歩道舗装の持ち上げと土猿硬度（深度 $2.0 \mathrm{~m}$ )

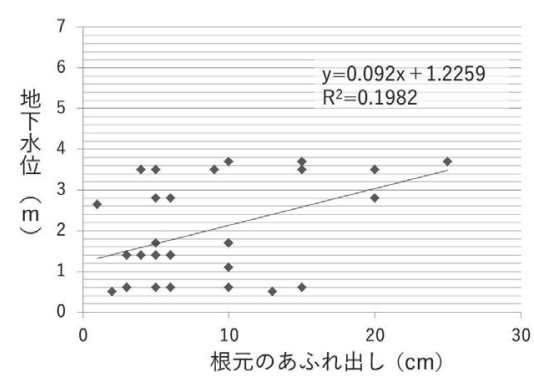

図－8＼cjkstart根元のあふれ出しと地下水位

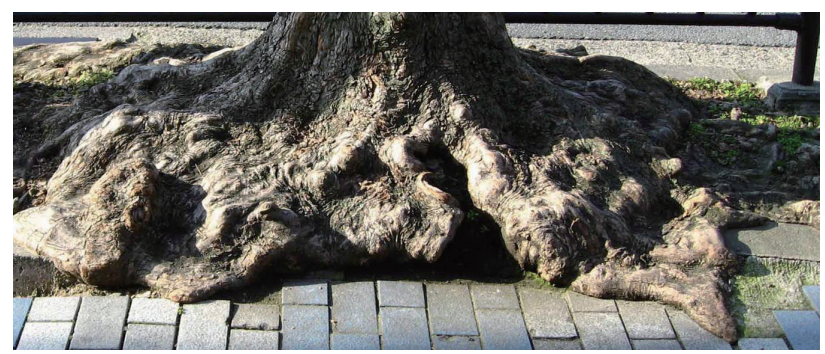

写真 -2 街路樹の根元部分の植樹栘からのあふれ出し

\section{3. 結果と考察}

\section{（1）街路樹の根上がり発生状況}

調查対象とする街路樹は 231 本となり, 調查対象通りにおける 街路環境構成を表一 -3 , 街路樹の根上がり発生状況の結果を表一 4 に示した。表一 3 をみると, 植樹桝形状としては単独栘が東側 で約 3 割, 西側で約 4 割, 連続栘が東側で約 7 割, 西側で約 6 割 であり, 植樹栘の奥行平均長さが $93 \mathrm{~cm}$ という構成であった。舗 装の種類はインターロッキングブロック舗装が東側は約 3 割, 西 側は約 5 割, アスファルト舗装が東側は約 7 割, 西側は約 5 割で, 歩道幅員が約 $4 \mathrm{~m}$ の街路環境である。表一 4 をみると, トウカエ デ街路樹の平均胸高周囲長は東側 $80.2 \mathrm{~cm}$, 西側 $78.5 \mathrm{~cm}$ であり, 根上がりの発生割合は東側 $41.2 \%$, 西側 $34.8 \%$ あったた。根上 がりの種類別にみてみると, 根元の上根部分のあふれ出し（縁石 を巻き込む）は東側 $21.0 \%$, 西側 $12.5 \%$ あ゙あ, 平均あふれ出 し長さは $7.7 \mathrm{~cm}$, 最大長さは $25.0 \mathrm{~cm}$ となっていた。縁石の持ち 上げは東側 $16.0 \%$, 西側 $15.2 \%$ であり, 平均長さは $3.1 \mathrm{~cm}$, 最大
長さは $30 \mathrm{~cm}$ であった。縁石のずれは東側 $20.2 \%$ ，西側 $14.3 \%$ ，平 均長さは $2.3 \mathrm{~cm}$, 最大長さは $6.0 \mathrm{~cm}$ であった。歩道舗装の持上げ は東側 $12.6 \%$, 西側 $22.3 \%$, 平均長さ $34.7 \mathrm{~cm}$, 最大長さ $75.0 \mathrm{~cm}$ であった。歩道舗装のひび割れは東側 $5.0 \%$, 西側 $12.5 \%$, 平均 長さ $82.6 \mathrm{~cm}$, 最大長さ $120.0 \mathrm{~cm}$ となっていた。歩道舗装の持上 げやひび割れは $1 \mathrm{~m}$ 以上の長さに達しているものもみられたが, 縁石之歩道舗装の持上げおよび縁石のずれなどが全体的に植樹栘 の近接部分でみられ，とくに根元の桝外へのあふれ出しはトウカ エデに特徵的にみられるものであると報告されており ${ }^{14)}$, これ は表一 1 に示した根系特性のうち, 垂直分布が浅根型, 水平分布 が中間型であることが関係しているのではないかと考えられた。

\section{(2) 対象通り周辺の土壤条件}

本調査では, 街路樹の植栽地点での土袞の性質とボーリング調 査地点での土壤の性質が同一であるという仮定のもと, 検討を行っ た。調查対象通りにおけるボーリングデータからみた土袞条件の 構成割合等を表一 5 に示した。土質抢よび土壌硬度は深さ $0.5 \mathrm{~m}$ ごとに記録されている。調査対象とした 231 本のトウカエデ街路 樹のうち, 深度によっては柱状図中に記録のないものもあるため, 各構成割合は, 深度ごとの有効調査街路樹数で土質別の街路樹数 を割った值とした。深度 $0.5 \mathrm{~m}$ では砂質土 $35.2 \%$, 粘性土 $32.2 \%$ ，有機質土 $9.1 \%$ ，その他 $23.5 \%$ という割合であった。平 均土質硬度相対值は 4.0 であった。深度 $1.0 \mathrm{~m}$ では砂質土 $42.9 \%$, 粘性土 $37.2 \%$, 有機質土 $9.5 \%$, その他 $10.4 \%$ であり, 硬度は 5.1 であった。深度 $1.5 \mathrm{~m}$ では砂質土 $51.3 \%$, 粘性土 $39.8 \%$, 有機質土 $4.0 \%$, その他 $4.9 \%$ であり, 硬度は 10.3 であっ た。深度 $2.0 \mathrm{~m}$ では, 砂質土 $50.7 \%$, 粘性土 $40.5 \%$, 有機質土 4.4\%, その他 $4.4 \%$ であり, 硬度は 14.7 であった。調査対象通 りの平均地下水位は $2.5 \mathrm{~m}$ となっていた。

\section{(3) 街路樹の根上がりと土壇条件との関連性}

図一 5 に, 最も地表に近いボーリングデータ深度 $0.5 \mathrm{~m}$ におけ る土質別の根上がり発生割合を示した。この図をみると, 砂質土 での根上がり発生割合は $44.6 \%$, 粘性土では $23.3 \%$, 有機質土

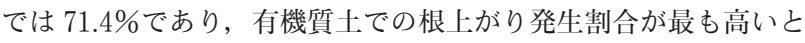
いう結果であった。土質ごとの他条件について多重比較 (Tukey 法）を行ったところ，表一 6 に示したように，植樹栘の奥行には 有意な差はみられなかったが，表－7 では，有機質土における平 均胸高周囲長が砂質土および粘性土の場合と比較して有意に大き く,これが発生割合の差異につながっていると考えられた。なお, 有機質土袞において平均胸高周囲長が最も大きいという結果につ いては，有機質土㙵での樹木の生育が他の土質よりも良好である ことが予想され，他の土質条件との数年間の生長率の差といった 観点からの調査が今後必要であると思われる。また, 表一 8 をみ ると, 有機質土に次いで根上がり発生割合が高かった砂質土では, 粘性土と比較して土袞硬度が有意に低い結果が示され，これが発

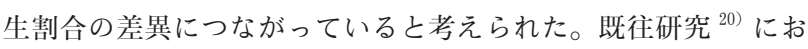
いては, 粘性土の場合は, 根系の発達が狭く浅いとされている。ま

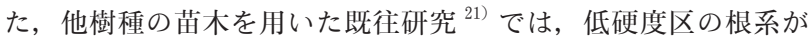
太く活力があり，非常に堅密に分布している状態が観察により認 められたと報告している。根系の範囲と土質との関係が，本調査 対象の根上がりの発生割合にも影響している可能性が考えられた。 表一 9 には, ボーリングデータからみた土壌硬度 ( $\mathrm{N}$ 值) と トウカエデ街路樹の根上がりの程度（長さと高さの実測值）との 関係についての検討結果を示した。検討にあたって, $100 \mathrm{~m}$ 範囲 ごとの街路樹 1 本 1 本のデー夕に対して入力した土袞硬度 ( $\mathrm{N}$ 值) との相関係数を算出した。この表をみると, 土壤硬度と根上がり の程度に有意な相関がみられたものは, 深度 $1.5 \mathrm{~m}$ の土㙵硬度と 根元のあふれ出し, 深度 $2.0 \mathrm{~m}$ の土㙵硬度之歩道舗装の持ち上げ であった。根元のあふれ出しは $0.532 （ \mathrm{p}<0.01 ）$ の正の相関がみ 
られ，歩道戥装の持上げは $-0.385 （ \mathrm{p}<0.05 ）$ の負の相関がみら れた。他条件に関しては, 深度 $1.5 \mathrm{~m}$ における土㙵硬度と街路樹 の胸高周囲長に $0.316(\mathrm{p}<0.05)$ の正の相関がみられた。

表一10 には, 地下水位と根上がりの程度との関係についての 検討結果を示した。この表をみると, 地下水位と根元のあふれ出 しとの間に $0.445(\mathrm{p}<0.05)$ の正の相関がみられた。

根元のあふれ出しは, 植樹栘下および近接した歩道下の土㙵硬 度が硬いほどその程度が大きくなるという可能性がみられ，これ は植樹栘下に根系が伸長しづらく地上部分での樹体維持および過 度な肥大生長 ${ }^{22)}$ が生じているためではないかと考えられる。写 真一 2 からは, トウカエデの根元の上根部分が生長し, 植樹桝の 範囲を超えて歩道舗装のほうへと伸長している様子が確認できる。 歩道の持ち上げや歩道のひび割れは, 主に水平方向に広がる根系 によるものであり, 植樹桝外の歩道下の土壤硬度が小さいほどそ の程度が大きくなる可能性がみられ，これは歩道下で広く伸長し やすいほど根量や根の周囲長も生長するためであると屯考えられ た。根元のあふれ出しとの地下水位に正の相関がみられた点は, 地下水位の高い環境と比較して, 地下水位の低い環境において, 根の生長分布が大きい可能性が考えられた。既往研究 ${ }^{20), 23)} に お ~$ いては, 地下水位が高い之直根が地中に入らず, 側根が地下水面 上に発達し, 高木は上長生長を抑制され, 樹木生育が阻害される といわれている。

しかし，図一 6 から図 -8 の散布図に示したように，いずれに ついても強い相関関係はみられず, この点は, 本調査結果全体が デー夕代替としてのボーリング調査デー夕の活用を試みたもので あり, 街路樹の直下に存在する植栽基盤を直接的に掘削し, 詳細 な調査を行っていないことが主要因であると考えられる。

一方で, 街路樹の根系は土袞改良が行われた植樹栘内のみでは なく, その大部分が植樹栘外に生育していたという報告や, 根系 の発達は表層に多いものの, 堅密な下層へも侵入しているという 報告がある ${ }^{4,}$ 22)。このことから, 今後も, 連続的な地下の土質 環境として, ボーリング調査デー夕を量的に検討していくことで, 全般的な土壤条件の把握につながっていく可能性が考えられた。

\section{3.おわりに}

本研究では, 多点では行われにくい掘削調査による土袞調査結 果を, 建築行為や災害対策のために行われるボーリング調査の結 果によって補完することを試みた。

このボーリング調査データからみた各種土㙵条件とトウカエデ 街路樹の根上がり発生状況との関連性を検討した結果, 本対象地 においては, 土質別にみると有機質土，砂質土，粘性土の順に根 上がり発生割合が高い結果となった。土壤硬度との関係について は, 根元のあふれ出しの項目は土㙴硬度と正の相関がみられ, 歩 道埔装の隆起の項目は土袞硬度と負の相関がみられ, これは, 根 系の垂直分布および水平分布との関連性が考えられた。地下水位 との関係については, 根元のあふれ出しの項目と負の相関がみら れ, これは地下水位が低いほど根の生長が大きい可能性が考えら れた。しかし，いずれについても強い相関関係はみられず，この 点は, 本調查がデー夕代替としてのボーリング調查データの活用 を試みたものであり, 街路樹の直下の植栽基盤を直接的に掘削調 査していないことが主要因であると考えられる。一方, こうした 代替の限界があるなかで, 土壌条件と街路樹の根上がりの関係に ついての知見とその可能性がみられ，量的には得られない掘削調 査の補完機能としての, 今後の検討の必要性も示された。加えて, ボーリングデータは街路樹に対して調査デー夕数が限られるため, 今後, 同樹種もしくは同様の根系特性をもつ他樹種での詳細な検 討が必要であると思われる。

また，本調查では京都市および全国での植栽本数上位種である
浅根性のトウカエデを用いたが，市内および全国での植栽本数第 1 位のイチョウや, サクラ, ケヤキといった他の上位種の検討や, 根上がりによる歩道破損の大きさおよび対策の必要性といった観 点からの検討が今後の課題である。

さらに, 本調査において, 街路樹扔よび土㙵条件の調査結果を 地理情報システム（GIS）を用いてデータベース化した点につい ては，各街路樹とボーリングデータとの位置関係の把握や各デー 夕同士の対応化に役立てることができた。今後, 積層データとし ての街路樹の長期的な維持管理への活用へ向けても有用であると 考えられる。

謝辞：本研究の遂行にあたり，京都市動物園長片山博昭様，同建 設局岩村謙次様には資料のご提供や調査へのご助言をいただき， 大変扔世話になりました。関西圈地盤情報ネットワーク様, 学術 研究協力としてデータベースをご提供いただき, 誠にありがとう ございました。ここに御礼申し上げます。

\section{補注及び引用文献}

1）中島宏（2012）：道路植栽の設計・施工・維持管理一安全な街路樹・ 危険な街路樹：財団法人経済調查会, $77,80,120$

2）小沢知雄 - 川上忠夫 - 北沢清 - 萩原信弘 - 近藤三雄 - 市村匡史 （1975）：街路樹の生態に関する基礎的研究－街路樹の生育状況と根 网栘土壌状態との関係について一：造園雑誌 39(1)，23-34

3）大貫直子・松本聰（1992）：街路樹のおかれている土壌環境：造園雑 誌 56(1)，39-44

4）岩田彰隆・木田幸男・甲野毅・苅住昇（1996）：ケヤキ街路樹の根系 生長が歩道に与える影響：ランドスケープ研究 59(5)，49-51

5）高橋輝昌・及川尚美・岡田悠・小林達明（2008）：千葉県松戸市の街 路樹の生育之植栽基盤の理化学的性質の関係：日緑工誌，技術報告 34(1), 231-234

6）飯塚康雄（2009）：街路樹の根系と植栽基盤の現況：日緑工誌 35(2), $262-266$

7）管尚子（2009）：街路樹の根上がり対策事例（歩行者にも樹木にもや さしく), 日緑工誌 35(2), 267-270

8）大川秀雄・栗原翔真（2007）：植物による歩道舗装の破壊に関する検 討, 舗装, 42(7), 21-24

9) 久保光 (2009)：県内街路樹の根上がり調査：福井県雪対策・建設技 術研究所, 年報地域技術, 22, 59-63

10）岡田隼人（2011）：神戸市内の街路樹の根上がり実態と街路舗装被害 の調査：兵庫県立淡路景観園芸学校平成 22 年度受託研究報告書, 15 2522

11）野島義照・田中克奉・永石憲道・児玉可奈子・三谷康彦・木田幸男 （2011）：4 種類の根系誘導耐圧基盤におけるクスノキ根系の生育特性： 日緑工誌 36(3) 431-437

12）久保光・乾義明・佐治健介（2009）：道路緑化樹木の生育による歩道 舗装の破壊対策 (防止) に関する試験研究その 2 : 福井県雪対策・建 設技術研究所年報「技術」，22，64-67

13）松江正彦・飯塚康雄（2008）：樹木の根上がり対策に関する調査 www.nilim.go.jp/lab/ddg/seika/nendopdf/814.pdf, www.nilim. go.jp/lab/ddg/seika/nendopdf/711.pdf

14）瀬古祥子・福井亘・水島真（2015）：京都市における街路樹の根上が りと植樹桝，舗装，日照条件との関係について：ランドスケープ研究 78(5), 501-504

15）京都市・京都市造園建設業協会（2013）：京都市近代街路樹 100 周年 記念誌, $79 \mathrm{pp}$

16) 苅住曻（2011）：最新 樹木根系図説各論：誠文堂新光社，691

17）京都市（2007）：平成 19 年度街路樹台帳，京都市

18）関西圈地盤情報データベース 2015 年度, http://www.kg-net2005.jp/ db01.html

19）国土地理院（2002）：数值地図 2500 （空間デー夕基盤）近畿 -2, 国土 地理院, CD-ROM

20）新田伸三（1975）：環境緑地(2) - 植栽の理論と技術：鹿島出版会，59 $73,200-229$

21）北村文雄・野田坂伸也（1974）：造園樹木の生長におよぼす土袞硬度 の影響 : 造園雑誌 38(4), 32-37

22) 苅住曻 (2011) : 最新 樹木根系図説総論 : 誠文堂新光社，499

23）森本幸裕（1985）：緑地における樹木生育基盤に関する研究：京都大 学博士論文, $150, p p 160$

（2016.4.29 受付，2017.9.20 受理） 